As the Nation's principal conservation agency, the Department of the Interior has responsibility for most of our nationally owned public lands and natural resources. This includes fostering the wisest use of our land and water resources, protecting our fish and wildlife, preserving the environmental and cultural values of our national parks and historical places, and providing for the enjoyment of life through outdoor recreation. The Department assesses our energy and mineral resources and works to assure that their development is in the best interests of all our people. The Department also has a major responsibility for American Indian reservation communities and for people who live in Island Territories under U.S. administration.

\section{Land Use \\ and \\ Land Cover and Associated Maps}

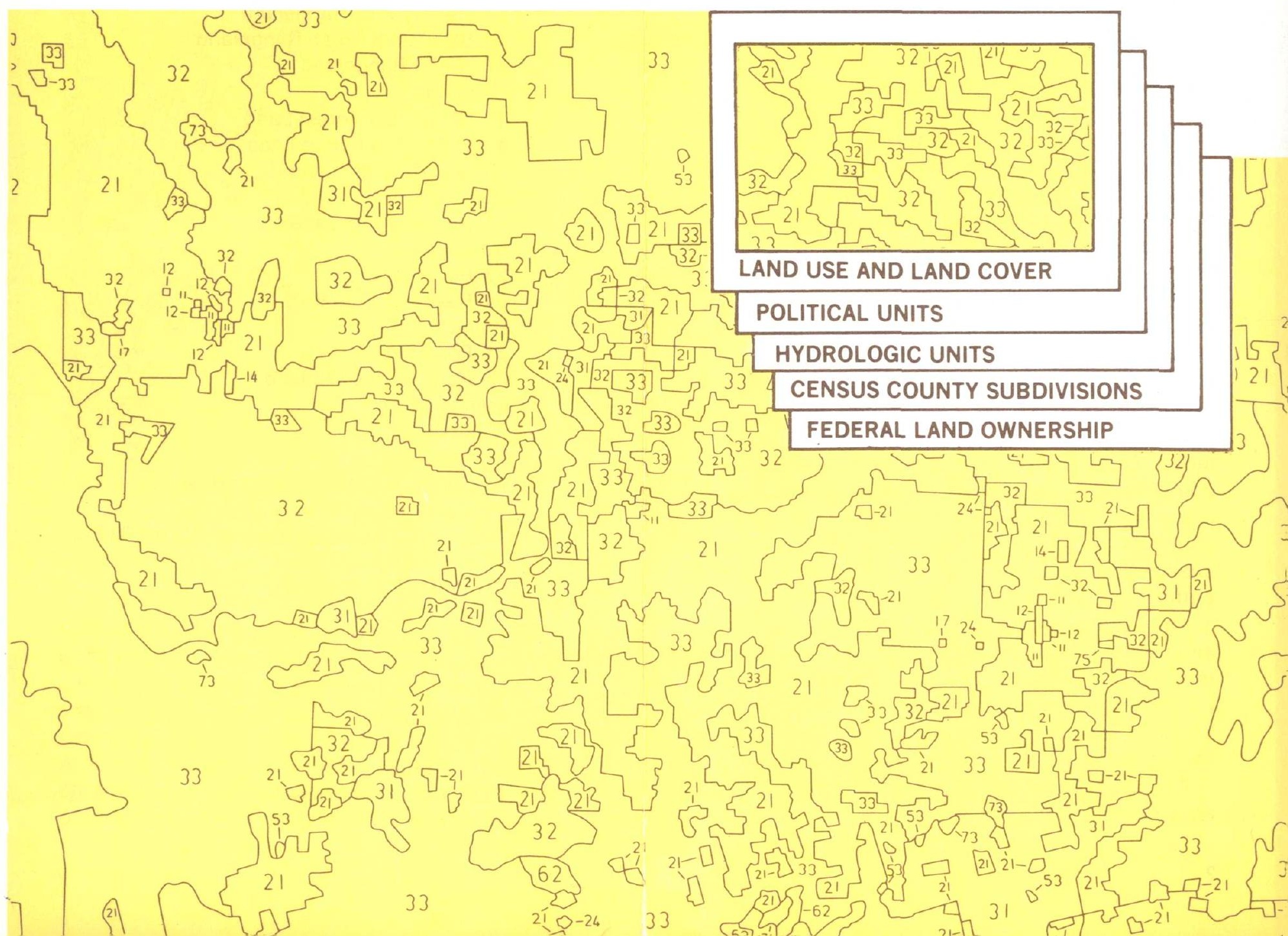




\section{Land Use \\ and \\ Land Cover \\ and Associated Maps}

The Geological Survey is compiling land use and land cover and associated maps for the entire United States. Land use refers to man's activities which are directly related to the land. Land cover describes the vegetation, water, natural surface, and artificial constructions at the land surface. These maps will help satisfy a longstanding need for a consistent level of detail, standardization of categories, and appropriate use of scales of compilation for a type of data frequently used by land use planners, land managers, resource management planners, and others. Specifically, these maps and data have been used for river basin planning, analysis of land use and land cover change on barrier islands in relation to recreational and other uses, river quality assessments, preparation of environmental impact statements, study of onshore impacts of offshore oil development, studies of urbanization, and other such studies at the multicounty regional, State, and Federal levels. Once the baseline series of maps is completed, the proposed updating of the maps will provide a much needed tool for analyzing trends and problems related to changes in land use and land cover patterns.

The land use and land cover maps are being compiled using a classification system that has a framework of nine general Level I categories that are further subdivided into 37 more specifically defined Level II categories.

The Level I and Level II land use and land cover categories are:
1 Urban or Built-up Land

11 Residential

12 Commercial

13 Industrial

14 Transportation, Communications, and Utilities

15 Industrial and Commercial Complexes

16 Mixed Urban or Built-up Land

17 Other Urban or Built-up Land

2 Agricultural Land

21 Cropland and Pasture

22 Orchards, Groves, Vineyards, Nurseries, and Ornamental Horticultural Areas

23 Confined Feeding Operations

24 Other Agricultural Land

3 Rangeland

31 Herbaceous Rangeland

32 Shrub and Brush Rangeland

33 Mixed Rangeland

4 Forest Land

41 Deciduous Forest Land

42 Evergreen Forest Land

43 Mixed Forest Land

5 Water

51 Streams and Canals

52 Lakes

53 Reservoirs

54 Bays and Estuaries

6 Wetland

61 Forested Wetland

62 Nonforested Wetland

7 Barren Land

71 Dry Salt Flats

72 Beaches

73 Sandy Areas Other Than Beaches

74 Bare Exposed Rock

75 Strip Mines, Quarries, and Gravel Pits

76 Transitional Areas

77 Mixed Barren Land

8 Tundra

81 Shrub and Brush Tundra

82 Herbaceous Tundra

83 Bare Ground Tundra

84 Wet Tundra

85 Mixed Tundra

9 Perennial Snow or Ice

91 Perennial Snowfields

92 Glaciers 


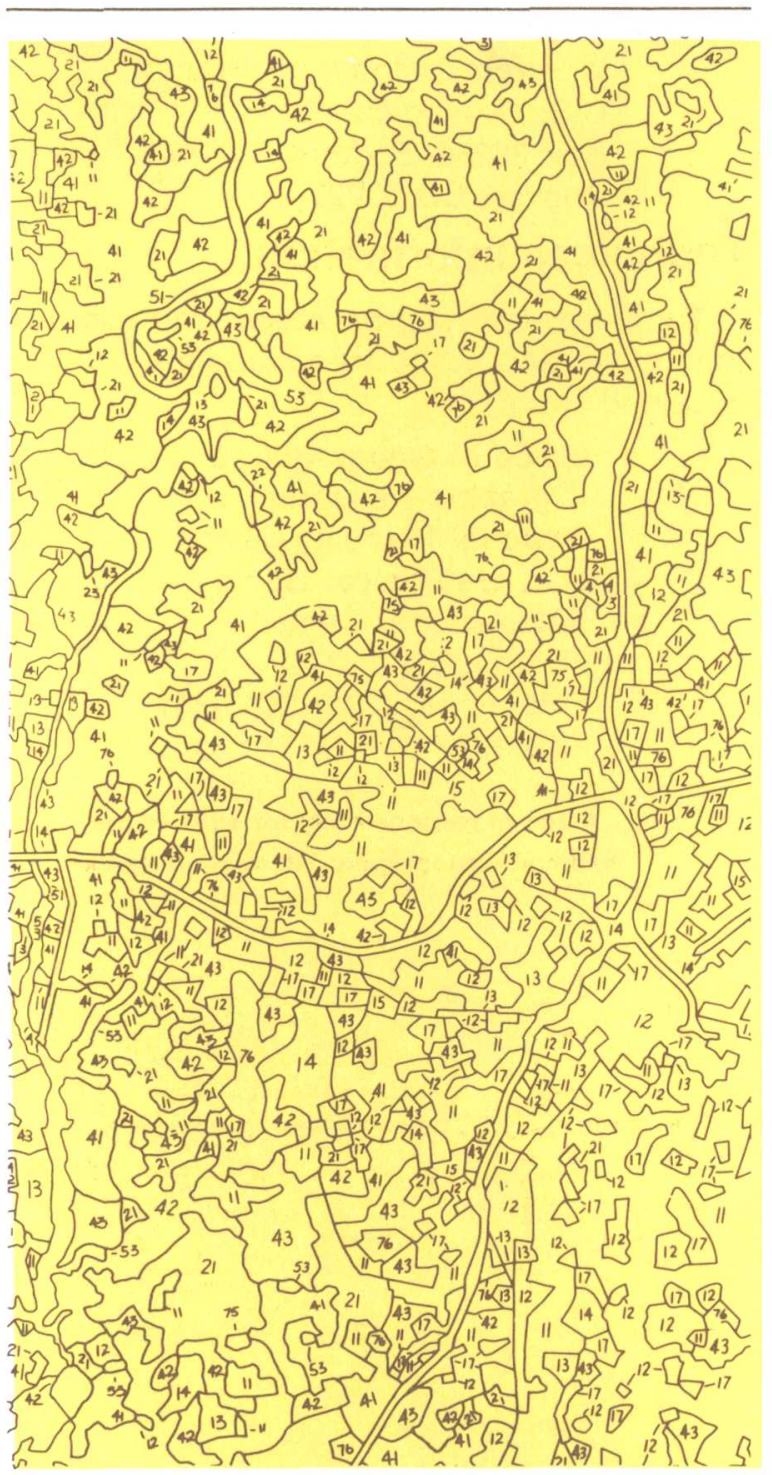

The area shown is a portion of the Charlotte, North Carolina, 1:250,000-scale land use and land cover map.

The classification system developed by the Geological Survey was reviewed by a committee of representatives from the Geological Survey, the National Aeronautics and Space Administration, the Soil Conservation Service, the Association of American Geographers, and the International Geographical Union, as well as by many others, and was designed to be used primarily with data obtained from remote sensors on aircraft and satellites. However, the system can also be used in classifying land use and land cover from field surveys. The system and the categories are explained in the U.S. Geological Survey Professional Paper 964, "A Land Use and Land Cover Classification System for use with Remote Sensor Data." This Professional Paper (at $\$ 1.75$ per copy) is available from:

\section{Eastern Distribution Branch}

U.S. Geological Survey

1200 South Eads Street

Arlington, VA 22202

When ordering, please enclose a check or money order payable to U.S. Geological Survey.

A mapping unit having a minimum size of 10 acres (4 hectares) is the smallest area mapped for all urban areas and bodies of water. It is also the minimum area mapped for surface mines, quarries, gravel pits, and certain agricultural areas. A minimum mapping unit of 40 acres (16 hectares) is used for all other categories. These minimum mapping units are the smallest areas appropriate for use on maps of 1:250,000 and 1:100,000 scales. Thus, a residential area less than 10 acres would not be shown on the land use and land cover map. Likewise, an area of cropland and pasture less than 40 acres would not be shown.

Aerial photographs and other remotely sensed data serve as the primary sources used in compiling the land use and land cover maps. Secondary sources include earlier land use maps and other maps prepared by field-survey methods. Such maps are generally available at larger scales and for small areas such as parts of metropolitan regions.

After compilation, the Survey's land use and land cover maps are field checked for accuracy if unresolved compilation problems exist.

\section{Associated Maps}

Sets of four associated maps are prepared at the same scale as the land use and land cover maps in order to relate the land use and land cover maps to other data. For example, land use data can be combined with the socioeconomic data compiled by the Bureau of Census by census county subdivisions or census tracts or can be compared to hydrologic data compiled for hydrologic units. These associated maps are:



\section{Base Maps and Map Scales}

The land use and land cover and associated maps are compiled on planimetric base maps prepared by the Geological Survey at scales of 1:250,000 (1 inch on the map represents about 4 miles on the ground) or $1: 100,000$ ( 1 inch on the map represents 1.57 miles on the ground). As more 1:100,000scale planimetric base maps become available, more map sets will be prepared at 
that scale. Most of the maps will be published at a scale of $1: 250,000$. Updating of land use and land cover maps will be at a scale of 1:100,000 for areas where such a scale should be used to properly represent complex land use and land cover patterns.

\section{Status of Available Maps}

The land use and land cover and associated maps currently available are shown in the "Index to Land Use and Land Cover and Associated Maps" published by the U.S. Geological Survey and available free from the Distribution Branches and NCIC offices.

After these maps are placed on open file, the land use and land cover maps are published in the $L$ series. On the $L$ maps a green base is used to show base map features and black is used to delineate the land use and land cover information. The availability of the $L$ maps is also indicated on the "Index" mentioned above.

\section{Ordering Maps}

Master sets of the land use and land cover and associated maps'for a particular area are on open file and are available for reproduction at the U.S. Geological Survey National Cartographic Information Center (NCIC) unit that has responsibility for that part of the United States, as shown on the map on page 9.

Reproductions of land use and land cover and associated maps can be made on the following types of material to permit a wide range of uses:

(1) Stable base film positive, clear or matte;

(2) Semi-stable diazo foil, matte; or

(3) Paper diazo.

Cost of reproduction varies with the type of material requested; the film positive is the most expensive and the paper diazo the least expensive. Current price information may be obtained from regional NCIC offices.

Copies of maps reproduced on the previously described materials may be purchased from:

Eastern National Cartographic Information Center

U.S. Geological Survey

536 National Center

Reston, VA 22092

Telephone: (703) 860-6336

FTS 928-6336

Mid-Continent National Cartographic Information Center

U.S. Geological Survey 1400 Independence Road

Rolla, MO 65401

Telephone: (314) 341-0851

FTS 277-0851

Rocky Mountain National Cartographic Information Center

U.S. Geological Survey

Box 25046, Stop 504, Federal Center

Denver, CO 80225

Telephone: (303) 234-2326

FTS 234-2326 .

Western National Cartographic Information Center

U.S. Geological Survey

345 Middlefield Road

Menlo Park, CA 94025

Telephone: (415) 323-8111, ext. 2427

FTS 467-2427

Printed copies of $L$ maps may be purchased for $\$ 2$ each (2 colors), as shown below:

Maps of areas east of Mississippi River, including Minnesota, Puerto Rico, and the Virgin Islands:

\section{Eastern Distribution Branch \\ U.S. Geological Survey \\ 1200 South Eads Street \\ Arlington, VA 22202}

Maps of areas wèst of Mississippi River, including Alaska, Hawaii, Louisiana, Guam, and American Samoa: 
Western Distribution Branch

U.S. Geological Survey

Box 25286, Federal Center

Denver, CO 80225

\section{Technical Information}

Technical information about land use and land cover and associated maps may be

obtained from:

Office of Geographic and Cartographic Research

National Mapping Division

U.S. Geological Survey

521 National Center

Reston, VA 22092

Telephone: (703) 860-6341

FTS 928-6341

Areas of responsibility for units of the National Cartographic Information Center
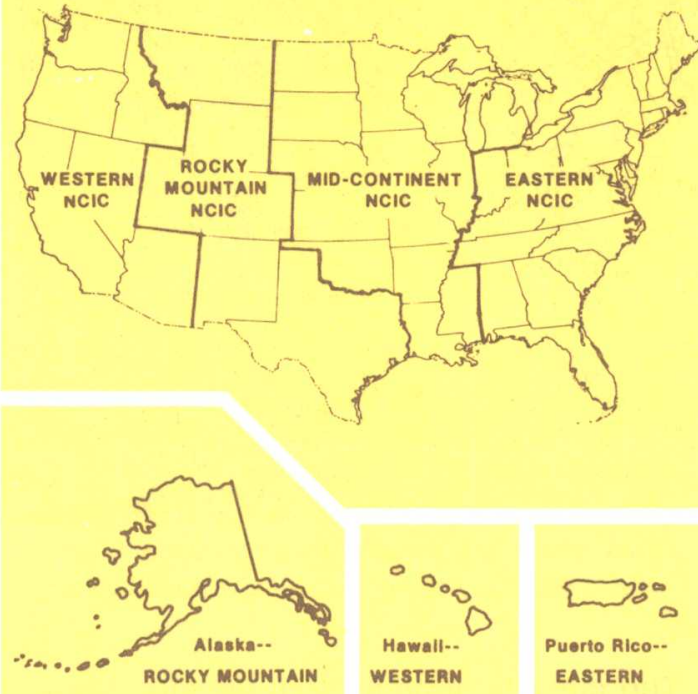

This publication is one of a series of general interest publications prepared by the U.S. Geological Survey to provide information about the earth sciences, natural resources, and the environment. To obtain a catalog of additional titles in the series "Popular Publications of the

U.S. Geological Survey," write:

Eastern Distribution Branch

U.S. Geological Survey

or Western Distribution Branch

604 South Pickett Stree U.S. Geological Survey

Box 25286, Federal Center

Alexandria, VA 22304

Denver, CO 80225 